\title{
PENDIDIKAN AGAMA ISLAM PADA ANAK USIA SEKOLAH DASAR DALAM KELUARGA DI KECAMATAN PEMANGKAT KABUPATEN SAMBAS
}

\author{
Rianawati ${ }^{1}$, Wasli $^{2}$ \\ ${ }^{1,2}$ Institut Agama Islam Negeri (IAIN) Pontianak \\ Email: irin_ptk@ymail.com
}

\begin{abstract}
Family roles have a huge influence on child education. The roles of each parent must complement each other, so that harmonization in the family can be realized through religious values in daily life. Family become the first place for education for a child, so the Islamic education in the family is very important because it will shape the child's personality. This study used a qualitative descriptive research method, so the results of this research were narrated in the form of descriptions. The data were gathered through observation and interviews where the major respondents were parents in Pemangkat. The data from the interview were analysed simultaneously, so that the data verification was also done simultaneously. The findings of this study revealed that the first religious education for the child was in the form of teaching things that are easy to understand, e.g. pronouncing asthma Allah, becoming close friends with them, forming good habit, encouraging the children to seek science by studying in the mosques. The widespread religious understanding in the family was later found in Pemangkat that Islamic educational materials were taught to children such as educational beliefs, religious education, moral education, primary teaching of Islamic education and reading the Qur'an. In Pemangkat, it was found that Islamic education in the family must pay attention to the Islamic faith, where faith is the essence of the foundation of faith one must be given to the child from an early age. In educating the children, the parents provided
\end{abstract}

materials about religion to children that is by using the method of storytelling, by giving examples, experiences and punishment.

Keywords: Children; Families; Islamic Education; Primary School.

Abstrak: Peran keluarga memiliki pengaruh yang sangat besar dalam pendidikan anak. Peran masing-masing orang tua harus saling melengkapi, sehingga harmonisasi dalam keluarga dapat dijalankan melalui nilai-nilai keagamaan dalam kehidupan sehari-hari. Keluarga menjadi tempat pendidikan pertama bagi seorang anak, sehingga pendidikan Islam dalam keluarga sangat penting karena akan membentuk kepribadian anak. Studi ini menggunakan metode penelitian kualitatif deskriptif, sehingga hasil penelitian ini berupa teks deskripsi. Data dikumpulkan melalui observasi dan wawancara dengan informan utama adalah para orang tua di Pemangkat. Analisis data dengan analisis hasil wawancara dan analisis hasil observasi yang dilakukan pada saat yang bersamaan dengan pengumpulan data, sehingga verifikasi data dilakukan secara bersamaan. Temuan penelitian ini mengungkapkan bahwa pendidikan agama pertama pada anak diajarkan hal-hal yang mudah dimengerti, misalnya mengucapkan kata asma Allah, berteman dekat dengan mereka, habituasi, pengawasan, dan anak juga diberitahu untuk mencari ilmu dengan belajar di Masjid. Pada pemahaman keagamaan yang meluas dalam keluarga 
ini kemudian ditemukan bahwa materi pendidikan Islam yang diajarkan kepada anak seperti pendidikan keyakinan, pendidikan agama, pendidikan moral, pengajaran utama pendidikan Islam dan membaca Al-Qur'an. Pendidikan Islam dalam keluarga harus memperhatikan iman Islam, di mana iman adalah inti dari dasar iman seseorang harus diberikan kepada anak sejak dini. Pendidikan oleh orang tua dalam menyediakan materi tentang agama kepada anak adalah dengan metode bercerita, memberi contoh, pengalaman dan hukuman.

Kata Kunci: Anak; keluarga; Pendidikan Islam; Sekolah Dasar.

\section{PENDAHULUAN}

Pendidikan adalah upaya yang sungguh-sungguh, kerja kerasn, kontinu dab berkesinambungan dalam mempersiapkan anak-anak kearah kedewasaan, 'baik jasmani dan rohani. Pendidikan agama adalah penanaman dan pengembangan nilai-nilai agama pada anak-anak yang mencakup keimanan, ketakwaan, akhlak mulia dan toleransi, agar anak-anak dapat menjalankan kehidupan yang harmoni, baik hubungan secara vertikal kepada Allah SWT maupun hubungan horizontal kepada sesama manusia dan lingkungan alam dalam mencapai kebahagiaan hakiki baik di dunia maupun di akhirat.

Islam menempatkan posisi yang sangat penting bagi orangtua sebagai pendidik yang pertama dan utama bagipengenalan, pendidikan dan pengamalan nilai-nilai agama kepada anak-anaknya. Oleh sebab begitu berartinya peran orangtua dalam pendidikan anak-anak, kemudian dalam surat At-Tamrim ayat 6 Allah memperingatkan setiap orangtua akan tanggung jawabnya terhadap pendidikan agama bagi anak-anaknya.

Pada fase awal tumbuh kembang anak, pendidikan dalam keluarga merupakan pendidikan yang utama.Artinya bahwa keluarga inti menjadi community primer yang paling penting dan utama, karena dari dalam keluarga terjadi komunikasi tatap muka, keakraban dan kekekalan. Hal ini yang dikemukanan Roucek \& Warren (1994) bahwasanya dari keluarga kita melangkah keluar dan kepada keluarga pulakita akan kembali. Dengan kata lain bahwa keluarga adalah tempat untuk berbagi dalam suka maupun duka.

Keluarga merupakan istitusi pertama yang memberikan pendidikan dan pengenalan nilai-nilai agama kepada anak, karena keluarga itulah seorang anak pertama kali mendapatkan pendidikan dari kedua orangtuanya. Artinya bahwa di dalam keluarga pula seorang anak akan mengalami proses pewarisan nilai-nilai dan kemudian menginternalisasikan nilainilai itu dengan lingkungan sosial terdekatnya. Selain itu, di dalam keluarga pula anak akan mendapatkan dasar-dasar nilai kehidupannya, khususnya nilai keadilan dan kesetaraan. Sementara di sekolah dan di masyarakat hanya menjadi tempat pengembangan dasar-dasar yang telah terbentuk sejak dalam keluarga (dalam UU Sisdiknas Nomor 20 Tahun 2003 dalam Bab IV pasal 7 ayat 1 dan 2).

Namun pada saat ini, kebanyakan orangtua mempercayakan pendidikan anak-anaknya pada pendidikan umum. Pendidikan agama dianggap tidak terlalu penting bagi masa depan anak-anak. Apalagi dengan bertambah majunya teknologi, anak-anak lebih mementing media sosial dan games daripada membaca 
dan menghafal al-Qur'an. Pelajaran agama hanya diperoleh di sekolah yang hanya bersifat formalistik dimana pelajaran agama hanya disampaikan oleh guru pada pengetahuannya saja, dengan mengabaikan aspek religius, sikap dan keterampilan beragama. Hal inilah yang akan semakin menjauhkan anak-anak pada keimanan, ketakwaan dan akhlakul karimah.

Sebagaimana dilansir dalam Pikiran Rakyat tahun 2017, dari sekitar 225 juta muslim di Indonesia,terdapat sebanyak 54\% diantaranya merupakan dalam kategori buta huruf al-Qur'an, artinya bahwa hanya terdapat $46 \%$ muslim yang bisa membaca al-Qur'an dan mampu membaca al-Qur'an. Jika dimasukan pada indikator memahami al-Qur'an tentu akan lebih kecil persentase jumlahnya. Kita ketahui bahwa Indonesia merupakan negara yang mayoritas berpenduduk Muslim terbesar di dunia, namun hanya sekitar $0.5 \%$ umat Islam di Indonesia yang mampu membaca al-Qur'an dengan baik. Tingkat buta huruf al-Qur'an di Indonesia masih terbilang cukup tinggi, tercatat $65 \%$ masyarakat Indonesia butu huruf al-Qur'an sebagaimana dilansir oleh Republika (17 Januari 2018) dari hasil Riset IIQ (Institut Ilmu Al-Qur'an) tahun 2018 (Wayuni, dkk., 2018).

Berdasarkan hasil riset yang dikemukakan di atas, menunjukkan bahwa terdapat banyak orang muslim di Indonesia yang masih belum bisa membaca teks alQur'an dan bahkan belum memahami isi kandungan al-Qur'an. Hal tersebut menandakan bahwa pendidikan agama Islam di Indonesia masih tergolong minim dan belum menjangkau semua kalangan, yang sekaligus menunjukkan bahwa pendidikan agama Islam dalam keluarga (di rumah oleh orang tua) belum dipandang menjadi suatu keutamaan.

Masyarakat di Kecamatan Pemangkat Kabupaten Sambas adalah masyarakat yang religius. Religiusitas tersebut tercermin dari tradisi keagamaan yang hidup dalam masyarakat Pemangkat. Pada awal perkembangan Islam, Pendidikan Agama Islam pada anak dalam keluarga di Kecamatan Pemangkatsudah menjadi tradisi kegiatan wajib. Tradisi Pendidikan Agama Islam pada masa lalu yang hingga hari ini masih menjadi tradisi masyarakat, seperti: kegiatan belajar membaca al-Qur'an di rumah guru ngaji yang dikenal dengan sebutan Pak Lebai. Kemudian, tradisi belajar agama di surau atau langgar secara bersama-sama antara murid dan guru, orangtua membiasakan anaknya shalat berjama'ah di masjid atau di rumah. Misalnya terdapat beberapa omongan pantang atau larangan yang diucapkan oleh anak kepada orang tua disebut pamali'k.Dengan kuatnya tradisitradisi dalam Pendidikan Agama Islam ini, sehingga di masa lalu Kecamatan Pemangkat dikenal sebagai Kecamatan Santri yang banyak melahirkan Qori'Qori'ah serta tokoh-tokoh agama yang cukup berpengaruh di Kabupaten Sambas.

Kondisi di atas berbanding terbalik dengan kenyataan pada Kecamatan Pemangkat saat ini, dimana Pendidikan Agama Islam untuk anak usia Sekolah Dasar sudah sangat jarang dilakukan oleh orang tua di dalam keluarga.Orang tua lebih banyak yang sibuk dengan pekerjaaannya sehingga di dalam keluarga Pendidikan Agama pada anaknya kurang diperhatikan. Akibatnya banyak anak usia Sekolah Dasar yang kurang memahami ajaran agama, bahkan untuk mengucapkan dua kalimah syahadat saja mereka belum 
baik. Kenyataan ini jelas mengejutkan karena dari pengamatan sementara, ada pergeseran yang signifikan pada masyarakat Kecamatan Pemangkat. Ada beberapa faktor yang menyebabkan terjadinya pergeseran tersebut, diantaranya adalah:

Pertama, Pemangkat merupakan salah satu daerah pelabuhan yang ada di Kabupaten Sambas. Pelabuhan tersebut bagi masyarakat Pemangkat merupakan satu diantara tempat melangsungkan kehidupan terutama dalam mencari sumber rezeki. Namun, selain itu pula lewat pelabuhan pendatang dari luar daerah Kecamatan Pemangkat datang baik dalam mencari pekerjaan, sehingga kehidupan masyarakat saat ini banyak dipengaruhi oleh pendatang terutama dalam segi berpakaian.

Kedua, Pemangkat merupakan daerah wisata pantai yaitu Tanjung Batu. Namun, pengelolaan tempat wisata tersebut kurang mendapat perhatian oleh pemerintah setempat padahal hal itu bisa meningkatkan pendapatkan masyarakat setempat. Kenyataan saat ini terlihat bahwa tempat wisata tersebut sudah tidak seindah dahulunya hal ini banyaknya sampah-sampah yang ada di sekitar pantai. Selain itu pula kalau malam hari tempat wisata tersebut sering sekali ditemukan anak-anak remaja dan dibawah umur yang mabuk, menghisap lem.

Ketiga, kuatnya arus modernisasi dan globalisasi hari ini, tidak terkecuali juga terpapar pada masyarakat di Pemangkat. Dengan ilmu pengetahuan dan teknologi yang sudah maju saat ini, mendesak atau menggeser nilai-nilai dikalangan orang tua untuk mempertahankan budaya dan sistem nilai yang telah mereka warisi. Hal ini terlihat bahwa banyak ditemukan anak-anak kalau waktu maghrib masih berkeliaran di jalan. Selain itu pula banyak anak-anak usia Sekolah Dasar yang perilakunya sama dengan orang dewasa seperti merokok, berpakaian tidak senonoh, serta ketika jam sekolah banyak pula terlihat anak-anak sekolah dasar yang nongkrong di warung internet untuk bermain game.

Masyarakat di Kecamatan Pemangkat lebih banyak mempercayakan Pendidikan Agama Islam anaknya di sekolah maupun di tempat-tempat pendidikan non formal seperti tempat penitipan anak (TPA) (berdasarkan hasil wawancara dan observasi lapangan penulis). Bagi keluarga yang mampu dari segi ekonomi, orangtua tidak segan untuk mendatangkan guru privat untuk mengajarkan anak-anaknya membaca teks al-Qur'ân. Bahkan bagi orangtua yang sibuk bekerja di luar rumah, pendidikan anaknya dipercayakan pada asisten rumah tanggayang bekerja di rumah mereka.

Melihat adanya pergeseran pemahaman dalam pendidikan agama ini dikhawatirkan akan semakin memperkecil pengaruh dan peranan keluarga pada anak. Hasil penelitian Munawiroh (2016) menyatakan bahwa penerapan pendidikan agama Islam dalam keluarga memiliki motif visi, dengan kata lain terdapat beberapa visi yang diinginkan para orang tua dalam memberikan pendidikan agama Islam terhadap anak-anak mereka, yaitu menjadi anak yang saleh dan salehah, menjadi seorang ahli agama, dan memiliki dasr agama yang baik dan benar.

Lebih lanjut, Hamzah (2015) mengungkapkan dalam hasil penelitiannya bahwa keluarga adalah wadah bagi pendidikan anak-anak, karena dalam pendididikan dilakukan transformasi nilai, 
informasi dan wacana. Kemudian, dampak berkurangnya peranan keluarga dapat dirujukkan pada hasil penelitian terhadap 15.000 remasa di Amerika Serikat, dimana efek dari kurangnya pendidikan anak dalam keluarga yaitu meningkatnya kasus hamil di luar nikah, kasus kriminal meningkat signifikan, serta meningkatnya sejumlah kasus patologi psikosial yang dilakukan anak.

Kemudian, merujuk hasil riset tersebut, US Department of Justice AS tahun 1988 menyatakan bahwa; tindakan kriminalitas dan kekerasan yang terjadi pada anak dikarenakan tidak adanya peranan keluarga dalam pendidikan anak. Hasil penelitian tersebut menyimpulkan bahwa bila peranan keluarga dalam pendidikan anak berkurang, terabaikan atau bahkan tidak dilakukan, dampaknya adalah peningkatan jumlah anak yang hamil di luar nikah, peningkatan kriminalitas yang dilakukan oleh anak atau remaja, dan meningkatnya patologi psikososial.

Pendidikan agama Islam (PAI) dapat didefinisikan sebagai studi tentang proses kependidikan yang bersifat progresif bagi anak, untuk menuju ke arah kemampuan optimal yang berlangsung di atas landasan nilai-nilai ajaran Islam (Arifin, 2003). Sementara itu, Achmadi (2005) memberikan pengertian tentang pendidikan Islam yaitu segala usaha untuk memelihara dan mengembangkan fitrah manusia yang juga mengembangkan sumber daya manusia (SMD) yang ada, dalam rangka menuju terbentuknya manusia seutuhnya (insan kamil) yang sesuai dengan norma dan nilai yang ada di dalam Islam.

Abdulah (2000) memberikan pengertian tentang pendidikan agama
Islam (PAI) yaitu usaha sadar untuk mengarahkan pertumbuhan dan perkembangan anak dengan segala potensi yang dianugerahkan oleh Allah kepadanya agar mampu mengemban amanat dan tanggung jawab sebagai khalifah Allah di bumi dalam pengabdiannya kepada Allah. Lebih lanjut, Abdurrahman an-Nahlawi (1996, dalam Rahkmat, 1994) pendidikan Islam adalah penataan individual dan sosial yang dapat menyebabkan seseorang tunduk taat pada Islam dan menerapkannya secara sempurna di dalam kehidupan individu dan masyarakat.

Pendidikan agama Islam pada dasarnya merupakan kebutuhan mutlak untuk melaksanakan dan mengamalkan ajaran Islam, sebagaimana yang dikehendaki oleh Allah SWT. Berdasarkan makna ini, maka pendidikan agama Islam sebenarnya mempersiapkan diri manusia yang utuhguna melaksanakan amanat yang diberikan Allah kepadanya. Hal ini berarti bahwa sumber-sumber dalam mengamalkan agama Islam dan pendidikan Islam itu adalah sama, yakni berpusat pada al-Qur'an dan Sunnah Rasul.

Lebih lanjut, Tafsir (1994) mendefinisikan pendidikan agama Islam adalah bimbingan oleh seseorang kepada orang yang lainnya agar dapat berkembang secara maksimal sesuai dengan ajaran Islam. Artinya bahwa, dalam keluarga pendidikan agama Islam yang diberikan oleh orang tua adalah dalam mempersiapkan anaknya menjadi manusia yang utuh.Berdasarkan pengertian ini, pada dasarnya pendidikan agama Islam adalah bimbingan yang dilakukan oleh satu orang tehadap orang lainnya agar menjadi Muslim semaksimal mungkin. 


\section{Hasil Penelitian}

Lebih lanjut, Syahminan Zaini (1986, dalam Maraghi, 1971) menyatakan bahwa pendidikan agama Islam adalah usaha dalam rangka mengembangkan fitrah manusia dengan ajaran Islam, dengan suatu tujuan tertentu yaitu agar terwujud (tercapai) kehidupan manusia yang makmur dan bahagia. Pada pengertian ini, PAI dikaitkan dengan suatu usaha dalam mengembangkan fitrah manusia dengan ajaran agama Islam serta dalam rangka terwujudnya kehidupan manusia yang makmur dan bahagia.

Berdasarkan konsep dasar dan pengertian yang dikemukakan tentang pendidikan agama Islam, Muhaimin (2003) menyebutkan bahwa pada dasarnya adalah mengandung pengertian; pertama pendidikan agama Islam yaitu pendidikan yang berdasarkan ajaran-ajaran Islam. Dengan kata lainbahwa pendidikan agama Islam yang dipahami dan dikembangkan dari ajaran dan nilai-nilai fundamental yang terkandung dalam al-Qur'an dan alSunnah. Dalam hal ini, pendidikan agama Islam sendiri dapat berwujud suatu pemikiran dan teori pendidikan yang dibangun dan dikembangkan dari sumbersumber dasar tersebut.Kedua, pendidikan agama Islam dapat diartikan sebagaiupaya mendidik agama Islam melalui ajaran dan nilai-nilainya agar menjadi way of life (pandangan hidup) dan sikap hidup seseorang. Kemudian, pendidikan agamaIslam yang menjadi way of life sendiri dapat berwujudkegiatan-kegiatan yang dilakukan seseorang untuk membantu orang lainnya atau sekelompok peserta didik dalam menanamkan dan menumbuh-kembangkan ajaran-ajaran dan nilai-nilai Islam.
Keluarga merupakan institusi pertama dan paling penting dalam kehidupan seseorang. Secara literal keluarga adalah unit sosial terkecil yang terdiri dari orang yang berada dalam seisi rumah yang sekurang-kurangnya terdiri dari suami, isteri dan anak. Secara normatif Ali (1980) menyebutkan bahwa keluarga merupakan sekumpulan orang yang terikat dalam suatu ikatan perkawinan yang kemudian bersama-sama untuk mencapai suatu kebahagian, kesejahteraan, dan ketenteraman semua anggota yang ada di dalam keluarga tersebut. Sebagai lembaga pendidikan utama bagi anak, sebuah keluargasenantiasa berusaha menyediakan kebutuhan bagi anak, baik kebutuhan biologis maupun psikologis yang afektif.

Apabila orangtua salah mendidik maka seorang anak dalam keluargabisa saja dengan mudah terbawa pada hal-hal yang tidak baik (negatif). Oleh karena itu,adanya peranan orangtua seharusnya saling melengkapi antara istri atau suami, sehingga dapat terbentuk keluarga yang utuh dan harmonis serta menjadi panutan bagi anak dalam menjalankan dan mengamalkan perintah agama dengan sebaik-baiknya.

Secara sosiologis menurut Rahmat (1994) keluarga dituntut untuk berperan dan berfungsi untuk menciptakan masyarakat yang aman, tenteram, bahagia dan sejahtera. Kemudian, semua itu harus dijalankan oleh suatu keluarga sebagai lembaga sosial terkecil dalam masyarakat. Lebih lanjut, Rahmat juga menjelaskan bahwa dalam masyarakat yang modernsaat ini, keluarga memiliki tujuh fungsi, yaitu: fungsi biologis, edukatif, religius, proyektif, sosialisasi, rekreatif dan ekonomi. 
Artikel ini menjelaskan mengenai bagaimana para orang tua mendidik agama anak-anaknya di Pemangkat Kabupaten Sambas. Apabila pada penelitian Hamzah (2015) dan Munawiroh (2016) lebih memfokuskan pada bagaimana keluarga meng-counter nilai-nilai agama kepada anak. Pada pembahasan ini difokuskan tentang materi pendidikan agama Islam yang diterapkan oleh orang tua pada anakanaknya dan metode apa saja yang dilakukan orang tua dalam pendidikan agama Islam di dalam keluarga, dan melihat faktor apa saja yang menjadi penghambat pendidikan Agama Islam pada keluarga di Pemangkat.

\section{METODE PENELITIAN}

Penelitian ini memfokuskan pada kegiatan Pendidikan Agama Islam pada Anak Usia Sekolah Dasar dalam Keluarga di Kecamatan Pemangkat Kabupaten Sambas. Berdasarkan fokus tersebut, maka metode penelitian yang digunakan adalah kualitatif dengan analisis deskriptif secara mendalam. Mengacu pada grand theory yang digunakan, maka paradigma penelitian ini mengacu pada paradigma integratif yang pernah diusulkan Ritzer \& Douglas (2004). Paradigma integratif merupakan penyatuan dari tiga paradigma, yaitu fakta sosial, definisi sosial, dan perilaku sosial. Alasan menggunakan paradigma integratif ini karena kompleksnya persoalan yang terkait dengan pendidikan agama kepada anak usia sekolah dasar di dalam keluarga Melayu Sambas. Hal ini seperti yang dikatakan Ritzer, teramat sukar untuk memahami fenomena sosial yang beraneka ragam dan saling pengaruh-mempengaruhi jika hanya menggunakan salah satu paradigma (Ritzer \& Douglas, 2004).
Berangkat dari paradigma di atas, maka pendekatan penelitian kualitatif yang digunakan adalah penelitian kualitatif interaktif, yang menurut McMillan \& Schumacher (2001) yaitu kajian yang mendalam dengan cara tatap muka dalam menghimpun informasi pada tatanan natural. Setiap fenomena yang diamati akan dimaknai oleh peneliti. Hal ini berarti bahwa seorang peneliti itu selalu berusaha untuk membuat gambaran yang utuh dan kompleks dengan menjabarkan pandangan subjek secara rinci (McMillan \& Schumacher, 2001).

Wilayah penelitian ini dilaksanakan di Kecamatan Pemangkat. Wilayah penelitian ini ditetapkan berdasarkan pertimbangan faktor biaya, tenaga dan waktu. Disamping itu dipilihnya kota kecamatan Pemangkat karena faktor geografisnya berada dipesisir laut, dimana pada umumnya masyarakat bermatapencaharian sebagai nelayan. Sejarah masa lalu, Pelabuhan Kota Pemangkat merupakan tempat persinggahan para pedagang Arab untuk melakukan transaksi perdagangan sekaligus menyiarkan agama Islam. Oleh sebab itu masyarakat Pemangkat berkembang menjadi masyarakat yang religius. Namun dengan semakin berkembangnya perekonomian kota Pemangkat memberikan dampak pada perubahan sosial masyarakatnya, sehingga masyarakat Pemangkat pada saat bercirikan masyarakat semi modern dan sudah mulai sedikit demi sedikit meninggalkan tradisi religius yang sudah membudaya sejak dulu. Kemudian, pendidikan agama Islam yang diterapkan dalam keluarga juga sudah mulai memudar yang merupakan akibat dari perkembangan teknologi. 
Adapun yang menjadi subjek di dalam penelitian ini adalah orang tua anak yang merupakan sumber dari pendidikan agama Islam dalam keluarga serta orangorang yang dianggap ahli sesuai fokus penelitian ini. Pengumpulan data penelitian melalui teknik wawancara dan observasi lapangan. Observasi yaitu aktivitas mencatat suatu gejala dengan bantuan-bantuan instrumen dan merekamnya dengan tujuan ilmiah (Morries, 1973). Kegiatan observasi ditujukan untuk mengamati kegiatan pendidikan agama Islam yang diterapkan dalam keluarga tertentu, yaitu kegiatan belajar shalat, mengaji, dan tausiyah. Disamping itu juga observasi juga dilakukan pada anak-anak yang belajar mengaji dan shalat berjamah di surau dan mdrasah ibtidaiyah.

Kemudian, pengumpulan data juga dilakukan dengan teknik wawancara mendalam. Wawancara mendalam adalah proses menggali informasi secara mendalam, dan terbuka (Moleong, 2007). Wawancara mendalam dilakukan terhadap 1 orang tokoh agama dan 4 orang warga setempat yang sudah memiliki anak. 4 orang informan orang tua diambil secara bertujuan dari desa yang berbeda-beda, untuk menggali pengalaman mereka melalui tanya jawab. Wawancara dilakukan untuk menggali data tentang kegiatan apa saja dalam keluarga yang menjadi pengenalan agama Islam pada anak-anak, lalu apa saja yang disampaikan oleh orang tua kepada anak-anak saat mengajarkan pendidikan Agama Islam. Analisis isi wawancara dilakukan pada saat peneliti di lapangan, kemudian verifikasi dilakukan setelah semua informan diwawancarai.

\section{HASIL PENELITIAN}

1. Metode Pendidikan yang diterapkan dalam Keluarga: Kasus di
Pemangkat

Dalam hal mendidik anak dikalangan masyarakat Pemangkat, peran ibu sangat besar dibandingkan dengan peran bapak/ayah. Peran ibu dalam mengasuh anak-anaknya mulai dari sejak lahir sampai umur dewasa, ibulah yang menggendongnya, memandikannya, menyuapinya, menidurkannya melindunginya dari keinginan. Kemudian ibu juga yang mengajarkannya makan, minum, berjalan, berbicaara, berpakaian, dan sebagainya.

Kemudian ibu juga yang mengajarinya makan, minum, berjalan, berbicara, berpakaian dan sebagainya. Kemudian ibu juga yang mendidiknyaberperilaku, bersikap sopan, santun, bahkan ibu juga yang menyuruh mengaji, belajar sampai mencarikan jodoh kadangkala ibu juga ikut menentukan. Jadi peran seorang ibu terhadap anakanaknya dikalangan masyarakat sangat besar dan sangat menentukan dalam pembentukan sikap dan perilaku anak. Sampai mendidik dan membimbing anakanaknya dalam bekerja. Sementara peran bapak/ayah terhadap anak-anaknya adalah dalam membimbing anak-anaknya bekerja.Utamanya bagi anak laki-laki, sosok ayah yang mengarahkan dan mengajarkan pekerjaan apa yang semestinya dilakukan oleh laki-laki.

Menurut Nasir, tokoh masyarakat yang diwawancarai, dalam pendidikan keluarga seharusnya orang tua memperhatikan anaknya. Anak harus dianjurkan untuk belajar agama, anak diajari sholat, puasa, mengaji, dan berbakti kepada orang tua. Begitu juga 
dalam pendidikan formal anak harus diberikan pendidikan agama, walaupun anaknya bersekolah umum, pada sore hari hendaknya sekolah di madrasah/sekolah agama. Menurut Nasir salah seorang tokoh masyarakat menjelaskan pentingnya orang tua memberikan perhatian terhadap pendidikan agama pada anak.

Anak-anak harus sering mendapatkan nasehat-nasehat agama, tentang pentingnya menjaga dan memperkuat aqidah dengan selalu menjaga keimanan dengan rajin melaksanakan shalat 5 waktu, rajin mengaji dan berpuasa wajib dan sunnah. Selain itu juga orang tua menasehati anaknya agar selalu berakhlak mulia dan menjauhi akhlak yang tercela. Menurut Abdurrahman al-Nahlawi (dalam Tafsir, 1994) menjelaskan bahwa metode nasehat dilakukan denganmenjelaskan tentang kebaikan dan kepentingan bersama, dengan tujuan mulia yaitu menghindarkan orang yang menerima nasehat dari bahaya serta menunjukkan jalan yang mendatangkan kebahagiaan dan manfaat.

Mba Sri (38) salah seorang masyarakat Pemangkatmenjelaskan bahwa pada setiap pengajian, ia senantiasa mengajak anaknya untuk ikut dalam pengajian. Alasan Mba Sri membawa anaknya adalah agar memberikan pengetahuan dan praktik-praktik keagamaan pada anaknya. Mbak Sri meyakinibahwa anak yang mengalami dan menyaksikan praktik keagamaan yang baik, teratur dan disiplin dalam keluarga akanmeniru dan menjadikan hal tersebut sebagai kebiasaan dalam hidupnya. Artinya bahwatindakan meniru ini akan membentuk si anak menjaditaat beragama. Dengan demikian, dapat ditegaskan bahwa agama tidak hanya dipelajari dan diketahui saja, tetapi juga dihayati dan diamalkan dengan konsisten.

Kemudian, Bapak Budiyanto (43) warga Pemangkat mengemukakan bahwa metode yang biasa ia gunakan dalam memberikan materi pendidikan agama Islam kepada anaknya adalah nasehat, teladaan, pembiasaan dan sekali-kali diberikan hukuman jika melakukan hal atau tindakan yang tidak benar. Lebih lanjut, pak Budiyanto menyatakan bahwa pendekatan secara prsonal kepada si anak dengan memberikan perhatian, kasih sayang, pujian bahkan hadiah untuk memberi semangat kepada si anak.

Para orang tua di Pemangkat pada umumnya masih konsisten mengawasi anak-anak mereka dalam melaksanakan ibadah dan berprilaku yang baik. Apabila mereka menemui anaknya tidak melaksanakan shalat, maka para orang tua akan menasehati anaknya agar segera melaksanakan shalat. Apabila anaknya berprilaku tidak santun atau berbuat suatu kesalahan, maka orang tua akan menasehati mereka untuk medukatifmperbaiki kesalahannya.

Kadang-kadang apabila anak masih melakukan kesalahan berulangulang maka orang tua juga akan memberikan sanksi atau hukuman ringan yang edukatif, sehingga menimbulkan efek jera pada anak agar tidak mengulangi kesalahannya. Metode pengawasan dan hukuman merupakan metode yang cukup efektif dalam rangka menunjang keberhasilan dalam pendidikan agama Islam dalam keluarga.

Pada masa dahulu di Pemangkat, semua anak belajar, rajin melaksanakan ibadah shalat, rajin berpuasa, mengikuti kegiatan keagamaan, berakhlak baik, 
terutama dalam tatakrama, tidak berani lewat di muka orang tua, kalau mau lewat di depan orang tua mengucapkan permisi dan menundukan kepala. Memang pendidikan akhlak sejak kecil sudah ditananamkan kepada anak- anak, begitu juga tentang tutur kata yang baik sudah dididik sejak kecil. Ahmadi dalam wawancara menyebutkan bahwa tata krama sejak umur empat tahun sudah diajarkan dan bahkan dipraktekkan.

Orang tua di Pemangkat sangat mementingkan pendidikan akhlak pada anak-anaknya. Kemudian, temuan pada penelitian ini menunjukkan bahwa peran ibu sangat dominan dalam pendidikan adab, baik adab berkata dan bersikap santun, adab makan dan berpakaian, adab bergaul pada orang yang lebih tua.

\section{Faktor Penghambat Pendidikan Agama Dalam Keluarga}

Berdasarkan data hasil wawancara dapat dikemukakan bahwa anak-anak di Kecamatan Pemangkat tergolong anak yang baik sesuai dengan karakter asli masyarakat, namun saat ini sikap mereka mengalami perubahan cukup besar, terutama pasca konflik etnis 1999. Selain itu pula pengaruh budaya-budaya luar juga sangat mempengaruhi terutama dalam hal berbusana dan bersikap. Dalam hal ini bahwa pendidikan anak harus dilaksanakan sejak dini sebagai dasar pembentukkan akhlak dan kepribadian anak secara utuh (Sudaryanti, 2012).

Menurut Sabarudin, seorang guru agama Islam, kalau dilihat dari tingkah laku anak saat ini dibandingkan dengan zaman dulu, mengalami penurunan, seperti ketaatan, kepatuhan, dan kesopanan anak terhadap orang tua sudah jauh berbeda dibandingkan dengan zaman dulu.
Meskipun dahulu pendidikan formal anak tergolong rendah, namun tingkat ketaatan dan kepatuhan anak terhadap orang tua sangat tinggi, tidak ada anak yang berani melawan orang tua, begitu juga melawan guru.Kehadiran televisi ikut merusak akhlak anak-anak, apalagi pada keluarga yang gemar menonton, bertingkah laku bermacam-macam terhadap orang sudah tidak dapat dilarang lagi. Lingkungan, tempat anak-anak bergaul, meskipun pada awalnya anak itu baik, tetapi akibat pergaulannya yang tidak baik sehinga menjadi rusak, akibat terkontaminasi teman-temannya

Menurut Syahran (23 September 2013), kepala aliyah swasta, pengaruh yang paling besar terhadap anak itu memang orang tua, pada umumnya orang tua kurang memperhatikan akhlak anakanaknya, bahkan dimanjakan. Sementara apa yang dikerjakan anaknya orang tua tidak pernah mengetahui, bahkan pulang jam berapa tidak pernah ditanya. Inilah yang paling merusak perilaku anak saat ini. Ajaran tentang akhlak memang sangat kurang, baik di sekolah, di rumah, di masyarakat, termasuk juga dari para penceramah hanya mengutamakan humor daripada materi yang disampaikan.

Terakhir, menurut Sabarudin, seorang guru agama Islam, usaha dari pihak pemerintah kabupaten itu sudah ada, misalnya melakukan razia terhadap anak yang berkeliaran apalagi jika dalam keadaan mabuk, akan ditangkap dan ditahan di kantor polisi kemudian baru dilepas sampai orang tuanya yang menjemputnya.Kehidupan agama keluarga di Pemangkat saat jauh berbeda dengan kehidupan keluarga di masa lalu. Tradisi keluarga di masa lalu lebih kental dengan nuansa keagamaan. Kini kegemaran orang 
tua dan anak menghadiri kegiatan seperti itu sudah jauh berkurang, misalnya dalam kegiatan ceramah agama, MTQ dan lainlain, sedikit sekali warga masyarakat yang mau menyaksikannya.Pola pendidikan yang kurang di rumah dapat disebabkan banyaknya kaum ibu yang bekerja di luar rumah sehingga meninggalkan kewajiban pendidikan kepada anak-anaknya. Apabila dahulu anak-anak diasuh oleh ibunya, sekarang peran ganda ibu tidak memungkinkan lagi melakukan pengasuhan anak seorang diri. Banyak anak dititipkan di lembaga pengasuhan atau orang lain (pengasuh) yang sengaja bekerja untuk mengasuh anak. Kondisi seperti ini memungkinkan tidak terjadinya transformasi nilai atau pendidikan akhlak oleh orang tua terhadap anak-anaknya.

\section{PEMBAHASAN}

Metode pendidikan agama Islam dalam keluarga pada dasarnya diawali dari kenyataan yang menunjukkan, bahwa materi pendidikan Islam tidak mungkin akan tepat diajarkan, melainkan diberikan dengan cara yang khusus. Ketidaktepatan dalam penerapan metode ini kiranya akan menghambat proses pembelajaran yang akan berakibat membuang waktu dan tenaga yang tidak perlu. Menurut Ahyadi (1991) metode adalah suatu cara atau jalan yang dilalui dalam mengajar. Sejalan dengan pendapat ini, Rianawati (1995) menyebutkan bahwa pendidikan dengan teladan berarti pendidikan dengan memberikan contoh, baik berupa tindakan, sifat, dan cara pikir. Dengan kata lain bahwa pendidikan dengan teladan merupakan metode yang cukup berhasil dalam keluarga

Metode yang sangat penting untuk diterapkan dalam pendidikan akhlak adalah pembiasaan.Menurut al-Taumy alSyaibany (dalam Rianawati, 1995) menjelaskan bahwa metode pembiasaan adalah melakukan sesuatu secara berulang-ulang sehingga menumbuhkan minat, kecenderungan yang selanjutnya menjadi adat istiadat dan kelakuan. Dengan metode pembiasaan, pembentukan kepribadian anak dan pembentukan sikap beragama diyakini akan berpengaruh. Hal ini terutama digunakan oleh orangtua dalam mengamalkan nilai-nilai dan moral kepada anak. Dengan harapan, si anakakan tumbuh kembang dengan budi pekerti yang luhur.

Nabi Muhammad Saw, dalam banyak hadits sering memperhatikan para sahabatnya dalam menyampaikan peringatan ketika melakukan kekhilafan, serta memberikan semangat kepada mereka yang berbuat baik (Soenarjo, dkk., 1988). Tujuan orang tua melakukan pengawasan adalah agar orangtua dapat mengetahui lebih dini kesalahan atau penyimpangan perilaku anak, maka orang tua dapat segera memperbaiki perilaku agar tidak terlalu parah kesalahan yang dilakukan oleh anak (Rianawati, 1995). Sedangkan metode hukuman sangat diperlukan bilamana keadaan tingkah laku anak sangat serius kenakalannya.karena mungkin akan membahayakan diri anak, baik rusaknya akhlak bahkan sampai pada jasmani anak. Menurut Siahaan (1991) tujuan memberikan hukuman adalah mengajar dan mendorong anak agar menghentikan sendiri tingkah lakunya yang salah.

Menurut Rianawati (2014) ibu berperan penting dalam pembinaan akhlak anak, oleh karena itu kelalaian ibu dalam pendidikan akhlak bisa jadi menyebabkan 
terjadinya krisis akhlak pada anak. Dalam hal ini, anak yang tidak memiliki akhlak terhadap Allah dan Rasul-Nya kemudian bersikap semaunya kepada siapapun, baik pada orang yang lebih tua maupun temanteman sebayanya. Masalah yang lebih besar kemudian adalahketika degradasi moral anak, bisa saja menyebabkananak terjebak pada tindak kriminalitas.

Berdasarkan data yang didapatkan, para orangtua di Pemangkat telah melaksanakan tradisi melaksanakan pendidikan baca al-Qur'an di surau-surau dimana anak-anak umumnya belajar mengaji dengan pak Guru mengaji. Anakanak belajar mengaji hingga dapat membaca al-Qur'an sendiri sampai 30 juz. Para orangtua pun masih melaksanakan tradisi menyekolahkan anak-anaknya di Madrasah.

Sudah menjadi tradisi umat Islam sejak jaman dahulu, bahwa pada umumnya para orang tua mempercayakan pendidikan agama anak-anaknya di lembaga-lembaga pendidikan Islam. Dalam konteks pendidikan anak, lembaga pendidikan berperan dalam membantu menggaantikan orang tua dalam pendidikan kecakapan, pengetahuan dan keterampilan. Artinya bahwa, peran lembaga pendidikan dan orang tua merupakan jalan bagi terbentuknya kepribadian anak (Huda, 2017). Kebiasaan membaca al-Qur'an setelah shalat mangrib sering terdengar di dalam rumah-rumah. Tadarus al-Qur'an merupakan bagian dari kehidupan warga masyarakat. Mendengar ceramah agama, mengunjungi tabligh akbhar, menghadiri MTQ adalah kegemaran mereka walaupun harus berjalan kaki yang cukup jauh dari kediaman mereka.
Kegiatan rutin membaca al-Qur'an di rumah-rumah warga, shalat Maghrib berjamaah di surau-surau, mendengar ceramah di masjid-masjid, mengunjungi tabligh akbar dan menghadiri MTQ sudah menjadi budaya dalam masyarakat di Pemangkat. Para orangtua mendidik agama anak-anak mereka dengan membiasakan anak-anak mereka mengikuti berbagai kegiatan yang sarat dengan materi agama dalam masyarakat. Tradisi keagamaan seperti ini sudah ada sejak dahulu kala, sehingga merupakan hal yang tabu apabila tidak diikuti. Para orang tuapun mewajibkan anak-anak mereka dari sejak kecil mengikuti berbagai kegiatan keagamaan ini.

Kebiasaan lokal yang dilakukan oleh para orang tua dalam pendidikan agama Islam pada anak di Pemangkat telah membudaya dalam kehidupan masyarakat, sehingga membentuk suatu norma atau perilaku tertentu dalam masyarakat tersebut. Horton (dalam Kastolani \& Yusof, 2016) menjelaskan bahwa budaya menentukan standar perilaku, karena budaya adalah sistem norma yang mengatur cara-cara merasa dan bertindak yang diketahui dan diikuti oleh anggota masyarakatnya. Penerapan norma-norma tersebut telah menjadi kebiasaan bagi anggotanya karena dilaksanakan berulang-ulang dan normanorma tersebut telah menjadi lazim bagi masyarakat lokal.

Kemudian, materi-materi pendidikan agama Islam dalam keluarga dapat disesuaikan dengan landasan dasar, fungsi dan tujuan yang termaktub dalam Ilmu pendidikan Islam secara teoritikal. Artinya bahwa materi pendidikan agama Islam dalam keluarga semestinya meliputi pendidikan akidah, pendidikan ibadah, 
pendidikan akhlak, dan membaca AlQur'an. Pendidikan agama Islam di dalam keluarga yang dilakukan sangat memperhatikan pendidikan akidah Islamiyah, di mana orang tua berpendapat bahwa akidah itu merupakan inti dari dasar keimanan seseorang yang harus ditanamkan kepada anak sejak dini.

Pendidikan akidah seharusnya ditanamkan kepada anak sejak dini, hal ini karena akidah merupakan dasar pedoman hidup seorang Muslim. Dengan kata lain bahwa pendidikan akidah merupakan dasar bagi seorang anak untuk mengenali siapa Tuhannya, bagaimana seharusnya cara ia bersikap terhadap Tuhannya dan apa saja yang harus diperbuat dalam hidup ini sebagai hamba Tuhan. Atas dasar ini, orang tua mempercayai bahwa setiap manusia yang belajar akidah akan tumbuh menjadi manusia yang beriman dan percaya akan Allah swt dengan segala sifat-sifatnya.

Islam sebagai agama akhir yang tetap mutakhir, mempunyai sistem sendiri yang bagian-bagiannya saling berhubungan dan saling bekerja sama untuk menapai tujuan. Materi pendidikan Islam meliputi akhlaq, aqidah, dan syari'ah. Akhlaq adalah budi pekerti, perangi, tingkah laku atau tabiat yang kita ketahui maknanya dalam percakapan sehari-hari (Ali, 1999). Pendidikan akhlak merupakan salah satu jiwa pendidikan agama. Mansur (2009) menyebutkan bahwa pendidikan akhlak yang pertama kali dilaksanakan di dalam lingkungan keluarga, hal ini karena keluarga memilki peranan penting dalam pendidikan akhlak untuk anak-anak sebagai institusi pendidikan pertama dan utama.

Lingkungan mempunyai pengaruh sangat besar dalam membentuk dan menentukan perubahan sikap dan perilaku seseorang. Menurut Daradjat (1992) diantara faktor yang menghambat pembinaan akhlak adalah pertama: Kaburnya nilai-nilai dimata generasi muda. Kedua: Kontradiksi yang ada dalam kehidupan generasi muda.

Pendidikan yang diberikan oleh orangtua kepada anak belumlah cukup untuk mengantarkan si anak menjadi manusia yang berkeperibadian Islam. Anak juga membutuhkan sosialisasi dengan lingkungan tempat dia beraktivitas, baik di sekolah, sekitar rumah, maupun masyarakat secara luas. Lingkungan masyarakat tidak dapat dikesampingkan dalam usaha membimbing dan membina anak-anak. Seorang anak yang terbiasa hidup dalam lingkungan yang baik, maka kelak dirinya juga akan tumbuh menjadi pribadi yang baik. Sebaliknya apabila anak dari kecilnya dengan lingkungan yang tidak baik, maka sudah dipastikan kelak anak dewasanya juga akan tumbuh dan berkembang menjadi orang yang tidak baik (Mukhtar, 2003).

Orang tua merupakan penanggung jawab pertama dan yang utama terhadap pendidikan agama pada anak-anaknya, melalui sikap dan pola hidup yang diberikan orang tua pada anaknya secara bertahap dan secara tidak langsung. Perhatian yang cukup dan kasih sayang orang tua menentukan tercapainya tujuan pendidikan agama anak-anaknya (Rianawati, 2017). Anak dilahirkan dalam keadaan suci. Orangtuanya-lah yang akan menentukan agama anaknya. Warna dan corak perkembangan kesadaran agama pada anak sangat dipengaruhi oleh keimanan, sikap, dan tingkah laku keagamaan orang tuanya (Ahyadi, 1991). 
Pedidikan agama dalam keluarga adalah pendidikan yang bersifat alami artinya anak-anak mengetahui dan belajar dengan sendirinya dengan melihat dan memperhatikan kehidupan dan bahkan kegiatan ibadah, prilaku orangtua di rumah. Oleh sebab itu apabila seorang ibu yang menitipkan anaknya pada tempat pengasuhan, mengakibatkan anak-anak tidak dapat belajar langsung kegiatankegiatan keagamaan, prilaku, dan anak tidak dapat merasakan kasih sayang ibunya (Rianawati, 2017:5).

\section{KESIMPULAN}

Berdasarkan hasil pembahasan dalam penelitian ini, dapat disimpulkan bahwa materi pendidikan agama Islam dalam keluarga di Pemangkat meliputi pendidikan akidah, pendidikan ibadah, pendidikan akhlak, dan membaca AlQur'an. Sedangkan faktor penghambat yaitu;pertamadari orang tua adalah kurangnya perhatian dan pemahaman dalam mendidik anak, pola hubungan antara orang tua dengan anak-anak yang secara intensitas sudah mulai berkurang, akibat kesibukan orang tua bekerja memenuhi kebutuhan hidup. Gaya hidup modern juga telah menyebabkan seorang ibu harus ikut bekerja dan berkiprahdi luar rumah. Konsekuensinya, pendidikan anak yang selama ini banyak dilakukan ibu di rumah menjadi tidak banyak dilakukan, sebab pengasuhan diserahkan kepada orang lain, baik anggota keluarga maupun pihak lain yang dibayar, disebabkan ketidaksiapan orang tuanya dalam mendidik anak atau tidak mengetahui cara mendidik anak yang baik. Sekarang ini, orang tua pada umumnya tidak begitu mengarahkan anak-anaknya untuk memilih sekolah yang baik, tetapi sepenuhnya diserahkan kepada anak, sedangkan kebanyakan anak melihat dan meniru kawan dan tetangganya. Kedua, dari anak itu sendiri, yang mana anak masih senang bermain-main dalam belajar. Ketiga,faktor kebebasan yang tak terkendali. Dahulu orangtua dalam mengasuh anak-anaknya tidak diberikan kebebasan seperti sekarangDan penghambat eksteren: terbatasnya keadaan ekonomi yang kurang baik. Keempat, perkembangan zaman menuntut adanya perubahan perilaku masyarakat yang secara otomatis akan meninggalkan tradisi lama.

\section{DAFTAR PUSTAKA}

Abdullah, A. S. (2000).Teori-Teori Pendidikan Berdasarkan AlQur 'an. Jakarta: Rineka Cipta.

Achmadi. (2005). Ideologi Pendidikan Islam. Yogyakarta: Pustaka Pelajar.

Ahyadi, A. A. (1991). Psikologi Agama Kepribadian Muslim Pancasila. Bandung: Sinar Baru.

Ali, H. N. (1999). Ilmu Pendidikan Islam.Jakarta: PT. Logos Wacana Ilmu.

Ali, M. M. (1980). Islamologi (Din alIslam) (terj. Kaelani dan Bahrun). Jakarta: Ikhtiar Baru.

Arifin, M. (2003). Filsafat Pendidikan Islam. Jakarta: Bumi Aksara.

Daradjat, Z. (1992). Kerjasama Guru dan Orang Tua Dalam Pembinaan Akhlak Anak. Pontianak: IAIN Press.

Hamzah, N. (2015). Pendidikan Agama Dalam Keluarga. Jurnal At-Turats. 9(2): 49-55. Doi: https://doi.org/10.24260/atturats.v9i2.315

Huda, Z.(2017). Sinergi Antara Lembaga Pendidikan Islam, Wali Murid, Dan Masyarakat Dalam Tanggung Jawab Pendidikan Islam. Program Studi Pendidikan Islam: Pasca Sarjana UIN Sunan Ampel. 
Kastolani., \& Yusof, A. (2016). Relasi Islam Dan Budaya Lokal. Jurnal Kontemplasi. $\quad 4(1):$ 51-74. Retrieved from: https://media.neliti.com/media/publ ications/67299-ID-relasi-islamdan-budaya-lokal-studi-tent.pdf

Mansur. (2009). Pendidikan Anak Usia Dini Dalam Islam. Yogyakarta: Pustaka Pelajar.

Maraghi, A. M. A. (1971).Tafsir al Maraghi. Semarang: CV. Toha Putra.

McMillan, J.H., \& Schumacher, S. (2001). Reseach in Education. New York: Longman, Inc.

Moleong. (2007). Metodologi Penelitian. Bandung: Remaja Rosdakarya.

Morries, W. (1973). The American Heritage Dictionary of English Language. Boston: Houghton Miffin.

Muhaimin. (2002). Paradigma Pendidikan Islam Upaya Mengefektifkan Pendidikan Agamalslam di Sekolah. Bandung: PT Remaja Rosdakarya.

Mukhtar. (2003). Desain Pembelajaran Pendidikan Agama Islam. Jakarta: Ghalis Indonesia.

Munawiroh. (2016). Pendidikan Agama Islam Dalam Keluarga. EDUKASI: Jurnal Penelitian Pendidikan Agama dan Keagamaan. 14(3): 345-365.

Doi: http://dx.doi.org/10.32729/edukasi. v14i3.6

Rakhmat, J. (1994). Keluarga Muslim dalam Masyarakat Moderen. Bandung: PT. Remaja Rosdakarya.

Rianawati. (1995). Peranan Ibu Dalam Pendidikan Anak Di Rumah. Jurusan Tarbiyah IAIN Syarif Hidayatullah Pontianak.

Rianawati. (2017). Peran Ibu Dalam Pendidikan Karakter Anak Dini Menurut Pandangan Islam. Jurnal Raheema. 1(1): 1-13. Doi: https://doi.org/10.24260/raheema.v $1 \mathrm{i} 1.146$
Ritzer, G., \& Douglas, J. G. (2004). Sosiologi Modern. Jakarta: Prenada Media.

Roucek, J. S., \& Warren, R. L. (1994). Pengantar Sosiologi (terj. Sahat Simamora). Solo: Bina Aksara.

Siahaan, H. N. (1991). Peranan Ibu Bapak Mendidik Anak. Bandung: Angkasa

Soenarjo, dkk,. (1988).Al-Qur'an dan Terjemahnya. Semarang: Toha Putra.

Sudaryanti. (2012). Pentingnya Pendidikan Karakter Bagi Anak Usia Dini. Jurnal Pendidikan Anak. 1(1):1-16. Retrieved from: https://journal.uny.ac.id/index.php/j $\mathrm{pa} /$ article/view/2902

Tafsir, A.(1994). Ilmu Pendidikan dalam Perspektif Islam. Bandung: Remaja Rosdakarya.

Wayuni, D., dkk. (2018). Al-Qur'an Literacy for Early Chilhood with Storyelling Tehniques. Obsesi: Jurnal Pendidikan Anak Usia Dini. 2(2):202-210.

Doi: https://doi.org/10.31004/obsesi.v2i 2.72 